\title{
Adenoid cystic carcinoma arising in association with pleomorphic adenoma in a background of chronic sclerosing sialadenitis (Küttner tumor)
}

\author{
Angela N. Viaene ${ }^{1}$, Bert W. O'Malley Jr. ${ }^{2}$, Virginia A. LiVolsi ${ }^{* 1}$ \\ ${ }^{1}$ Department of Pathology and Laboratory Medicine, Anatomic Pathology, Hospital of the University of Pennsylvania, \\ Philadelphia, PA, USA \\ ${ }^{2}$ Department of Otorhinolaryngology, Head and Neck Surgery, Hospital of the University of Pennsylvania, Philadelphia, PA, USA
}

Received: October 13, 2015

Accepted: November 8, 2015

Online Published: February 16, 2016

DOI: $10.5430 /$ crcp.v3n1p61

URL: http://dx.doi.org/10.5430/crcp.v3n1p61

\begin{abstract}
Chronic sclerosing sialadenitis of the salivary gland is associated with IgG4 containing plasma cell infiltrate and fibrosis. Other manifestations of IgG4 disease may be present while salivary gland neoplasms are rarely seen. Here we describe the case of a 77-year-old male who presented with chronic right submandibular gland swelling that was diagnosed as pleomorphic adenoma on fine needle aspiration. He underwent right submandibular gland resection, and the pathology showed an adenoid cystic carcinoma with a high proliferative index and perineural invasion arising in association with a pleomorphic adenoma. The background salivary gland was consistent with chronic sclerosing sialadenitis. Clinical follow-up revealed markedly elevated serum IgG4 levels and radiologic findings consistent with diffuse autoimmune pancreatitis. While the association between neoplasms and IgG4-related salivary gland disease is unclear, this case emphasizes the importance of ruling out malignancy and thoroughly evaluating for systemic IgG4-related disease in the setting of chronic sclerosing sialadenitis.
\end{abstract}

Key Words: Chronic sclerosing sialadenitis, IgG4, Adenoid cystic carcinoma, Küttner tumor

\section{INTRODUCTION}

Chronic sclerosing sialadenitis, also known as Küttner tumor, is a fibroinflammatory disease of the salivary glands, classically occurring in the submandibular gland. Clinically, this disease presents as a firm swelling and is often mistaken for malignancy. ${ }^{[1,2]}$ Over the past decade, studies have shown chronic sclerosing sialadenitis to be an IgG4-related disease, occasionally associated with systemic symptoms. ${ }^{[3-5]}$ Chronic sclerosing sialadenitis itself is a benign entity and only rarely has been found in association with salivary gland neoplasms. ${ }^{[6,7]}$ Here we present the first reported case of pleomorphic adenoma and adenoid cystic carcinoma arising in a background of chronic sclerosing sialadenitis.

\section{Case presentation}

A 77-year-old male presented with a non-painful, gradually enlarging mass in his right submandibular region. He reported noticing the mass 3 years prior and denied a history of sialoliths. His past medical history is significant for chronic renal insufficiency, hypothyroidism, gout, hyperlipidemia and hypertension. He reported a remote smoking history (having quit over 30 years ago) and occasional alcohol con-

\footnotetext{
* Correspondence: Virginia A. LiVolsi; Email: linus@uphs.upenn.edu; Address: Department of Pathology and Laboratory Medicine, Hospital of the University of Pennsylvania, 3400 Spruce Street, 19104, Philadelphia, PA, USA.
} 
sumption. Magnetic resonance imaging was obtained which showed a $4.0 \mathrm{~cm} \times 2.9 \mathrm{~cm} \times 2.5 \mathrm{~cm}$ enhancing mass centered in the anterior-inferior aspects of the right submandibular gland which was not well encapsulated and contained a central area of non-enhancement. Fine needle aspiration of the mass showed pleomorphic adenoma (benign mixed tumor). He underwent right submandibular gland resection and right suprahyoid neck dissection 4 months later.

The resected specimen measured $6.7 \mathrm{~cm} \times 3.6 \mathrm{~cm} \times$ $2.1 \mathrm{~cm}$ overall and was dissected to reveal a mass measuring $4.9 \mathrm{~cm} \times 3.2 \mathrm{~cm} \times 3.1 \mathrm{~cm}$ and lymph nodes measuring from $0.4 \mathrm{~cm}$ up to $1.1 \mathrm{~cm}$ in greatest dimension. The cut surface of the mass was firm and tan-white with irregular borders. Adjacent salivary gland tissue measured $3.2 \mathrm{~cm} \times 1.1 \mathrm{~cm} \times$ $0.8 \mathrm{~cm}$, was pale in color and firm in texture (see Figure 1).
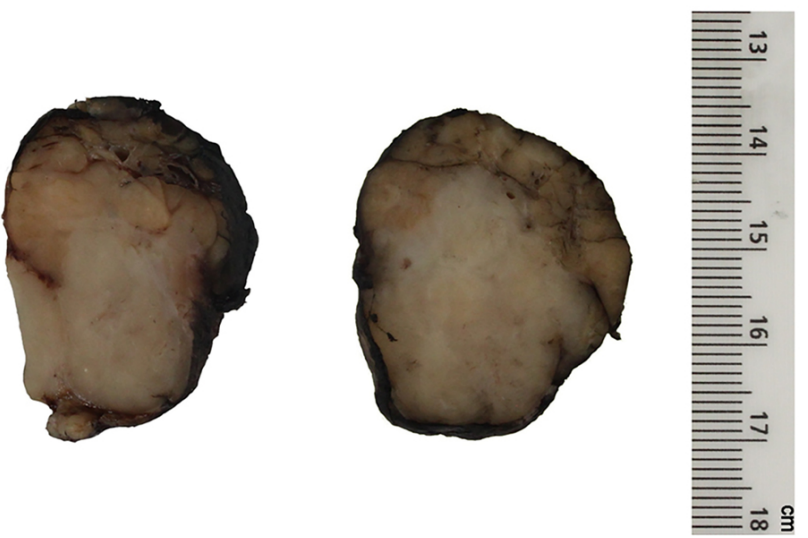

Figure 1. Gross specimen

Representative cut sections of the specimen showing a firm, tan-white mass with irregular borders. Adjacent salivary gland tissue (seen above the mass) was pale in color and firm in texture.

Histologic sections showed a pleomorphic adenoma $(4.9 \mathrm{~cm})$ which was partially involved by an intermediate-grade adenoid cystic carcinoma $(2.0 \mathrm{~cm})$. The carcinoma showed a cribriform pattern with tubular areas and foci of perineural invasion with no extraparenchymal extension. Because a portion of the tumor was an adenoid cystic carcinoma, immunohistochemical stains for c-KIT (CD-117), EGFR, Her2 and $\mathrm{Ki}-67$ were performed. Carcinoma cells were positive for c-KIT (moderate-strong and diffuse) and EGFR (moderate and diffuse) and negative for Her2. Proliferative index by Ki-67 immunostain was $40 \%-50 \%$ within the adenoid cystic carcinoma (see Figure 2) while it was less than $2 \%$ in the pleomorphic adenoma. Four identified lymph nodes were negative for tumor.

In addition, the background salivary gland tissue showed marked inflammation and lobular atrophy with germinal centers and fibrohistiocytic pattern of sclerosis forming nod- ules. Immunostains for CD138 and IgG4 showed numerous plasma cells, of which $80 \%-90 \%$ of the plasma cells were positive for IgG4. The number of IgG4 plasma cells averaged 113 per high power field (see Figure 3 ).

Evaluation for systemic IgG4-related disease was performed, and the patient's serum IgG level was found to be $2,360 \mathrm{mg} / \mathrm{dl}$ (reference range: $650 \mathrm{mg} / \mathrm{dl}-2,000 \mathrm{mg} / \mathrm{dl}$ ) with a markedly elevated serum IgG4 of $581 \mathrm{mg} / \mathrm{dl}$ (reference range: $7 \mathrm{mg} / \mathrm{dl}$ - $89 \mathrm{mg} / \mathrm{dl}$ ). A CT scan of the abdomen revealed findings consistent with diffuse autoimmune pancreatitis with no other systemic signs of IgG4 disease. He underwent radiation therapy for adenoid cystic carcinoma.

\section{Discussion}

Chronic sclerosing sialadenitis (Küttner tumor) is a relatively rare, underreported entity that is now associated with IgG4 disease. ${ }^{[2,3]}$ Histologically, it appears as a chronic, sclerosing inflammatory lesion with marked lymphoplasmacytic infiltrate, formation of lymphoid follicles, and acinar atrophy. Obliterative phlebitis can also be observed. ${ }^{[3,4]}$ As with other IgG4-related diseases, a ratio of IgG4 positive plasma cells to IgG plasma cells greater than $40 \%$ is seen; ${ }^{[8]}$ though it should be noted this definition is still not universally accepted for the diagnosis of IgG4-related disease in tissue section. Additionally, over $100 \mathrm{IgG} 4$ positive plasma cells per high power field should be present for the diagnosis of IgG4 disease in salivary gland tissue. ${ }^{[8]}$ Our tumor showed an average of 113 IgG4 positive plasma cells per high power field with IgG4 positive cells representing $80 \%-90 \%$ of all plasma cells; obliterative phlebitis was not present.

Systemic symptoms associated with IgG4 disease have been reported in association chronic sclerosing sialadenitis including autoimmune pancreatitis, retroperitoneal fibrosis, tubulointersitital nephritis, mediastinal lymphadenopathy, sclerosing cholangitis, and peribronchiolitis. ${ }^{[3,9-13]}$ The patient in this case showed radiologic evidence of autoimmune pancreatitis without other signs of systemic IgG-4 related disease on abdominal imaging. Of note, the patient has a history of renal disease and hypothyroidism, both of which can be associated with IgG4-related disease. ${ }^{[8,14]}$

Another IgG4 disease involving salivary glands is Mikulicz's syndrome ${ }^{[14]}$ which is characterized by enlargement of the parotid and/or lacrimal glands and is associated with Sjögren's syndrome. The patient in this case did not have apparent lacrimal gland or parotid gland involvement and showed no clinical signs of Sjögren's syndrome.

Chronic sclerosing sialadenitis was once associated with sialoliths ${ }^{[15]}$ though more recent work has demonstrated sialoliths are present only in a minority of cases. ${ }^{[3,16]}$ 
Sialadenitis with stones appears different morphologically; and response to steroids can help in making the diagnosis of squamous metaplasia is more frequently seen while a marked this entity. Chronic sclerosing sialadenitis has rarely been increase plasma cells and serpiginous fibrosis are not ob- reported with other neoplasms, specifically only salivary duct served. This patient denied any history of salivary stones. carcinoma and marginal zone B-cell lymphoma ${ }^{[6,7]}$ and to Chronic sclerosing sialadenitis and other IgG4-related le- our knowledge, has never been reported in association with sions can be mistaken clinically and radiologically for malig- a benign neoplasm (including pleomorphic adenoma) or an nancy while serologic tests, histologic examination of tissue, adenoid cystic carcinoma.

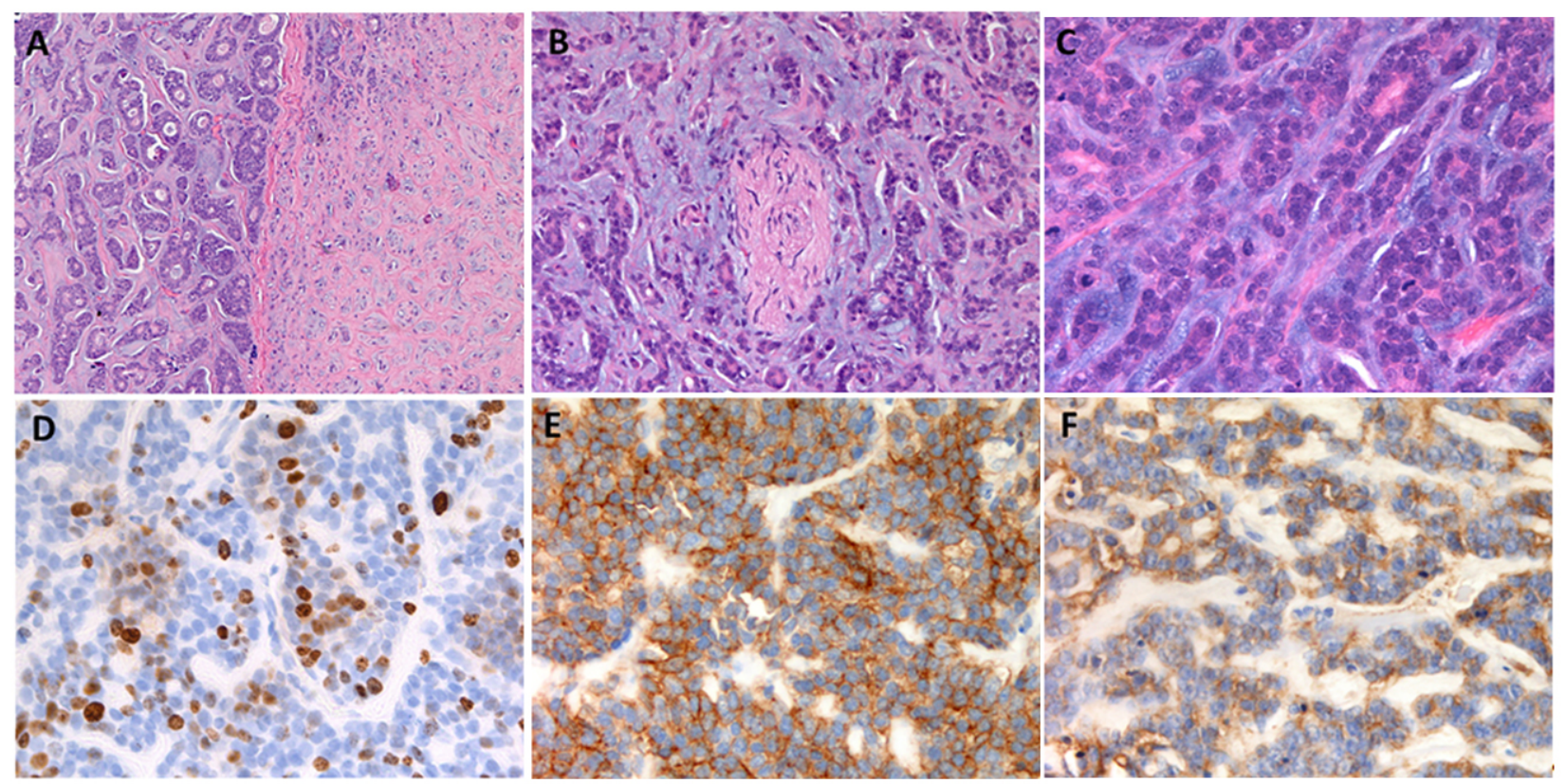

Figure 2. Histology of adenoid cystic carcinoma and pleomorphic adenoma

(A) Border between the intermediate-grade adenoid cystic carcinoma (left) and pleomorphic adenoma (right) $(H \& E, 10 \times)$.

(B) Perineural invasion within the adenoid cystic carcinoma $(H \& E, 20 \times)$. (C) High power view of the adenoid cystic carcinoma showing multiple mitoses $(H \& E, 40 \times)$. (D) Ki-67 immunostain of the adenoid cystic carcinoma showing a high proliferative index ( $H \& E, 40 \times)$. (E) c-Kit immunostain of the adenoid cystic carcinoma showing moderate-strong and diffuse staining $(40 \times)$. (F) EGFR immunostain of the adenoid cystic carcinoma showing moderate and diffuse staining $(40 \times)$.
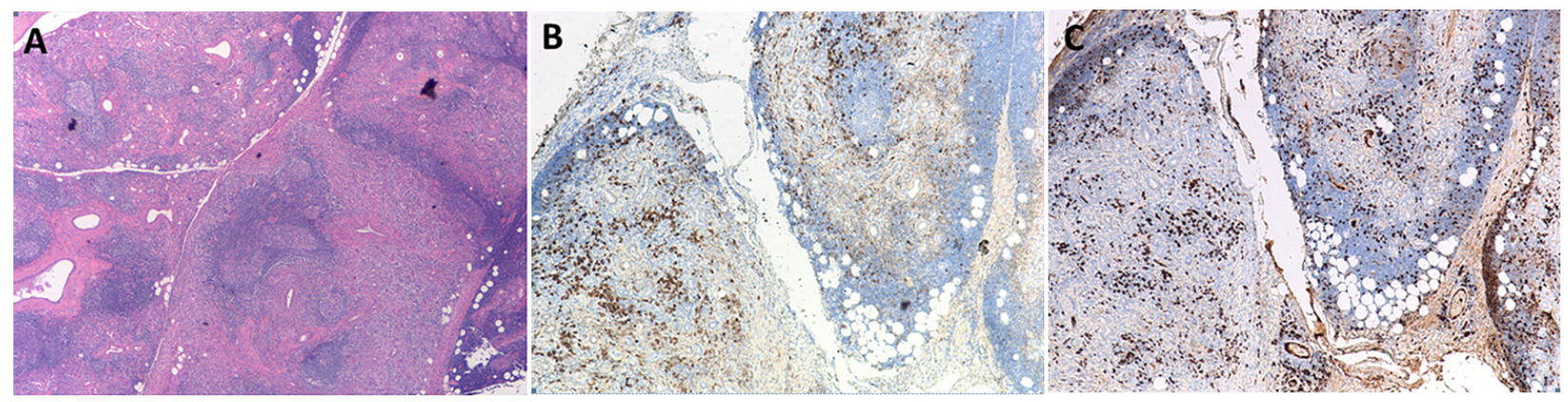

Figure 3. Chronic sclerosing sialadenitis (Küttner tumor) histology and immunostains

(A) Salivary gland tissue with marked inflammation, lobular atrophy, germinal centers, and fibrohistiocytic pattern of sclerosis, consistent with Küttner tumor $(H \& E, 2.5 \times)$. (B) CD138 immunostain highlighting numerous plasma cells within the salivary gland (5×). (C) IgG4 immunostain showing $80 \%-90 \%$ of the plasma cells stain positively for $\operatorname{Ig} G 4(5 \times)$.

In addition to the novelty of these two neoplasms arising within the background of chronic sclerosing sialadenitis, this case contains the additional rare entity of adenoid cystic carcinoma ex pleomorphic adenoma. While carcinoma ex pleomorphic adenoma accounts for approximately $12 \%$ of malignant salivary gland tumors, fewer than 10 well docu- 
mented cases of adenoid cystic carcinoma ex pleomorphic adenoma have been reported in the literature. ${ }^{[17]}$

Here we describe an exceptionally rare case of benign and malignant neoplasms arising in the submandibular gland, specifically adenoid cystic carcinoma arising in a pleomorphic adenoma, within a background of chronic sclerosing sialadenitis. While the association between these neoplasms and IgG4-related disease is unclear, this case emphasizes the importance of ruling out malignancy and evaluating for systemic IgG4-related disease in the setting of chronic sclerosing sialadenitis.

\section{CONFLicts OF InTEREST Disclosure}

The authors declare no conflicts of interest.

\section{REFERENCES}

[1] Küttner H. Ueber entzündliche Tumoren der submaxillarspeicheldrüse. Beiträge zur Klinischen Chirurgie. 1896; 15: 815-28.

[2] Chow TL, Chan TT, Choi CY, et al. Kuttner's tumour (chronic sclerosing sialadenitis) of the submandibular gland: a clinical perspective. Hong Kong Med J. 2008; 14: 46-9. PMid: 18239243.

[3] Kitagawa S, Zen Y, Harada K, et al. Abundant IgG4-positive plasma cell infiltration characterizes chronic sclerosing sialadenitis (Küttner's tumor). Am J Surg Pathol. 2005; 29: 783-91 PMid: 15897744. http://dx.doi.org/10.1097/01.pas.0000 164031.59940.f c

[4] Geyer JT, Ferry JA, Harris NL, et al. Chronic sclerosing sialadenitis (Küttner tumor) is an IgG4-associated disease. Am J Surg Pathol. 2010; 34: 202-10. PMid: 20061932. http://dx.doi.org/10.10 97/PAS. Ob013e3181c811ad

[5] Laco J, Ryska A, Celakovsky P, et al. Chronic sclerosing sialadenitis as one of the immunoglobulin G4-related diseases: a clinicopathological study of six cases from Central Europe. Histopathology. 2011; 58: 1157-63. PMid: 21438912. http://dx.doi.org/10.1111/j $.1365-2559.2011 .03833 . \mathrm{x}$

[6] Ochoa ER, Harris NL, Pilch BZ. Marginal zone B-cell lymphoma of the salivary gland arising in chronic sclerosing sialadenitis (Küttner tumor). Am J Surg Pathol. 2001; 25: 1546-50. PMid: 11717546. http://dx.doi.org/10.1097/00000478-200112000-00012

[7] Gill J, Angelo N, Yeong ML, et al. Salivary duct carcinoma arising in IgG4-related autoimmune disease of the parotid gland. Hum Pathol. 2009; 40: 881-6. PMid: 19200575. http://dx.doi.org/10.10 16/j.humpath. 2008.10.020

[8] Deshpande V, Zen Y, Chan JK, et al. Consensus statement on the pathology of IgG4-related disease. Mod Pathol. 2012; 25: 1181-92. PMid: 22596100. http://dx.doi.org/10.1038/modpathol.2 012.72

[9] Sekine S, Nagata M, Watanabe T. Chronic sclerosing sialadenitis of the submandibular gland associated with idiopathic retroperitoneal fibrosis. Pathol Int. 1999; 49: 663-7. PMid: 10504530. http://dx.doi.org/10.1046/j.1440-1827.1999.00926.x
[10] Gill J, Taylor G, Carpenter L, et al. A case of hyperIgG4 disease or IgG4-related sclerosing disease presenting as retroperitoneal fibrosis, chronic sclerosing sialadenitis and mediastinal lymphadenopathy. Pathology. 2009; 41: 297-300. PMid: 19291547. http://dx.doi.org/10.1080/00313020902756394

[11] Seki N, Yamazaki N, Kondo A, et al. Spontaneous regression of lung lesions after excision of the submandibular gland in a patient with chronic sclerosing sialadenitis. Auris Nasus Larynx. 2012; 39: 212-5. PMid: 21571470. http://dx.doi.org/10.1016/j.anl .2011 .01 .025

[12] Quinn B, Harty J, Habeichi W. A masquerading mass: an unusual presentation of IgG4-related systemic disease with tubulointerstitial nephritis. J R Coll Physicians Edinb. 2014; 44: 122-5. PMid: 24999772. http://dx.doi.org/10.4997/JRCPE. 2014. 206

[13] Sun L, Zhou Q, Brigstock DR, et al. Focal autoimmune pancreatitis and chronic sclerosing sialadenitis mimicking pancreatic cancer and neck metastasis. World J Gastroenterol. 2014; 20: 17674-9. PMid: 25516685. http://dx.doi.org/10.3748/wjg.v20.i46 .17674

[14] Deshpande V. IgG4-Related disease of the head and neck. Head Neck Pathol. 2015; 9: 24-31. PMid: 25804380. http://dx.doi.org/1 $0.1007 / \mathrm{s} 12105-015-0620-6$

[15] Harrison JD, Epivatianos A, Bhatia SN. Role of microliths in the aetiology of chronic submandibular sialadenitis: a clinicopathological investigation of 154 cases. Histopathology. 1997; 31: 237-51. PMid: 9354894. http://dx.doi.org/10.1046/j.1365-2559. 1997. 2530856.x

[16] Pandarakalam C, Goebel WM, Seyer B. Chronic sclerosing sialadenitis or Küttner's tumor associated with a giant sialolith: a case report. Oral Surg Oral Med Oral Pathol Oral Radiol. 2013; 115: e38-40. PMid: 23312536. http://dx.doi.org/10.1016/j.oooo.2012 .10 .011

[17] Ide F, Mishima K, Yamada H, et al. Adenoid cystic carcinoma ex pleomorphic adenoma of the parotid gland. Head Neck Pathol. 2009; 3: 159-62. PMid: 19644550. http://dx.doi.org/10.1007/s12 105-009-0108-3 